\title{
Arenaceous foraminifera from the Llandovery/Wenlock boundary beds of the Wenlock Edge area, Shropshire
}

\author{
J.E. MABILLARD \& R.J. ALDRIDGE \\ Shell International Petroleum Co. Ltd, c/o Petroleum Development Oman, \\ P.O. Box 81, Muscat, Sultanate of Oman \& Department of Geology, \\ The University, Nottingham NG7 2RD, England.
}

\begin{abstract}
Several thousands of specimens of arenaceous foraminifera have been collected from two sections in Shropshire that span the Llandovery/Wenlock boundary. Preservation in limestone samples is superior to that in shales, but both lithologies yielded abundant specimens. The uppermost Purple Shales, of Llandovery age, contain numerous Ammodiscus exsertus, together with Webbinelloidea tholus, Psammosphaera cava, Hemisphaerammina and Hyperammina. A faunal change occurs close to the base of the Wenlock, with the lower beds of the Buildwas Formation containing rather fewer foraminifera; assemblages here are dominated by Hyperammina, Lagenammina and Lituotuba? This event probably reflects a change in sea-floor environment, with habitats favoured by epifaunal encrusters and browsers contracting at the end of the Llandovery.
\end{abstract}

\section{INTRODUCTION}

Literature on Silurian foraminifera from Britain is very sparse. They were first recorded by Smith (1881), who found "Lagena-like" bodies in ostracod collections from the Wenlock of Shropshire. Brady (1888) subsequently described Smith's material together with additional specimens from the Woolhope Limestone Formation of the Malvern Hills, referring them all to the genus Lagena. Cummings (1952) restudied the specimens and, on the basis of the composition and structure of the test wall, assigned them to the parathuramminacean genus $\mathrm{Sac}$ camminopsis; from Brady's illustrations it appears that the textulariid genus Lagenammina may also be represented. Other collections of Silurian foraminifera have been reported by Ireland $(1958,1967)$ and by Aldridge et al. (1979), but these records are very brief and lack description or illustration of the assemblages.

In the course of a detailed micropalaeontological study of the Llandovery/Wenlock boundary beds of the Welsh Borderland we have recovered many thousands of specimens of arenaceous foraminifera. The vast majority of these are from the type area of the Wenlock Series, along Wenlock Edge in Shropshire. In this paper we present an outline of these foraminiferal assemblages and illustrate the common taxa.

\section{MATERIAL}

Fifty-five samples were collected for this study from two sections in the type Wenlock area, at "Leasows" (SO 5688 9839) and "Domas" (SJ 5958 0077) (Fig. 1). The Leasows section is the International Stratotype for the base of the Wenlock Series (Bassett et al., 1975; Holland, 1980) and the Domas section exposes a parallel sequence. At both localities there is a conform- able transition from soft maroon shales and mudstones of the Llandovery Purple Shales to olive-grey silty shales of the Wenlock Buildwas Formation.

Samples were collected as closely as possible and included all lithologies at each locality. Sample horizons and lithologies are shown in Fig. 2. Soft shales were disaggregated with petroleum spirit followed by hot water, limestones were digested with acetic acid; all residues were washed through a $75 \mu \mathrm{m}$ sieve. All samples, except the bentonitic clay (24/12), yielded diverse microfossils, including abundant arenaceous foraminifera.

\section{Abundance and preservation}

Absolute abundances have not been determined, as many samples yielded thousands of specimens. Estimates vary from tens of thousands per kilogram in the Purple Shales to several hundreds of specimens in the Buildwas Formation. At some horizons, assemblages are dominated by a profusion of one or more species, particularly Ammodiscus exsertus Cushman. Similar significant increases in abundance have been reported by Amsden et al. (1981) from the Silurian of Oklahoma; they refer to these events as "floods".

The quality of preservation and the relative frequency of species vary considerably with changes in lithology. Specimens with inflated chambers are compressed or completely crushed in shales, but excellently preserved, undistorted material occurs in the acid-insoluble residues of limestones. Low diversity assemblages, composed almost exclusively of $A$. exsertus were recovered from shales in the Purple Shales, whereas carbonates from 


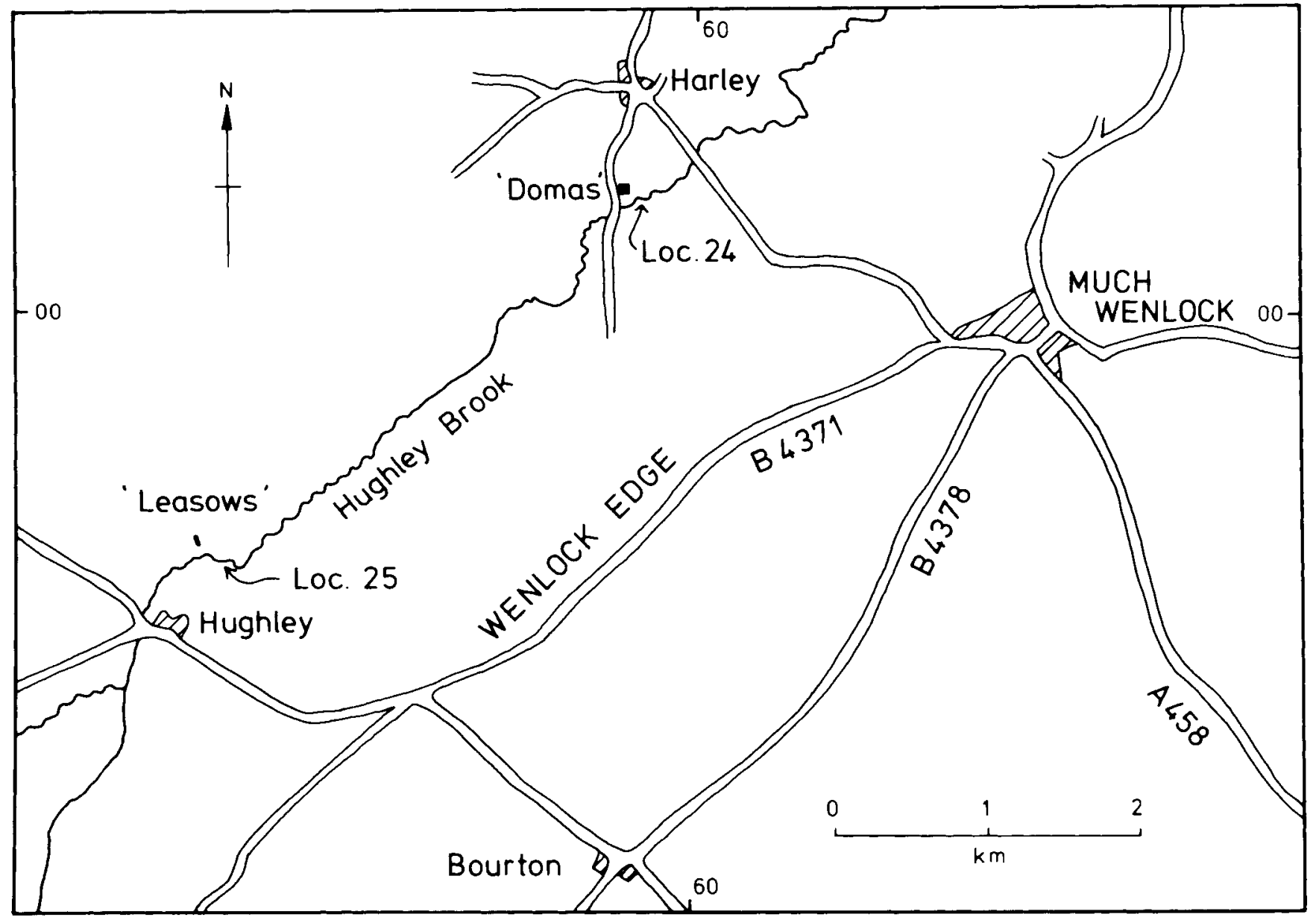

Fig. 1. Locality map for the two sampled sections.

these beds yielded more varied faunas. This appears to be due to selective preservation, as the differences are even apparent between limestone nodules and shales from the same bed.

\section{The foraminiferal assemblages}

The distribution of foraminifera through the two sampled sections is shown in Fig. 3. Llandovery shale samples at both localities are characterised by $A$. exsertus, in association with species of Hyperammina. Limestone samples from the Purple Shales contain abundant $A$. exsertus together with Webbinelloidea tholus (Moreman), Psammosphaera cava Moreman and Hemisphaerammina. Limestones from the Buildwas Formation do not contain these species, and $A$. exsertus disappears in the lowermost Wenlock beds. Assemblages from the Buildwas Formation contain smaller numbers of foraminifera than the Purple Shales and are characterised by representatives of the genera Hyperammina, Lagenammina and Lituotuba?

By far the most abundant species in the collections is
A. exsertus. The populations of this species include a number of distinct morphotypes, some of which have previously been given separate specific status. Similarly wide variation in $A$. exsertus has also been recognised by Amsden et al. (1980), who concluded that many forms are the result of aberration and do not merit taxonomic separation. In our samples, planispirally coiled specimens with an exsert neck (Pl. 2, fig. 6) account for more than $50 \%$ of the total. About $30 \%$ are considered to be damaged or immature specimens which lack an exsert neck (Pl. 2, fig. 7) and approximately $20 \%$ may be regarded as aberrant forms. These include multiplechambered, planispirally coiled forms, previously referred to $A$. furcus Moreman (Pl. 2, figs. 8-10), forms with irregular coiling, previously assigned to Lituotuba exsertus Moreman (Pl. 2, figs. 15-16), and forms with a partially detached final whorl previously designated as L. recurva Mound (Pl. 2, figs. 11-14).

Simple, straight or branching, tubular species are also abundant, although almost all our specimens were recovered from shales. Straight or slightly curved tubes of 


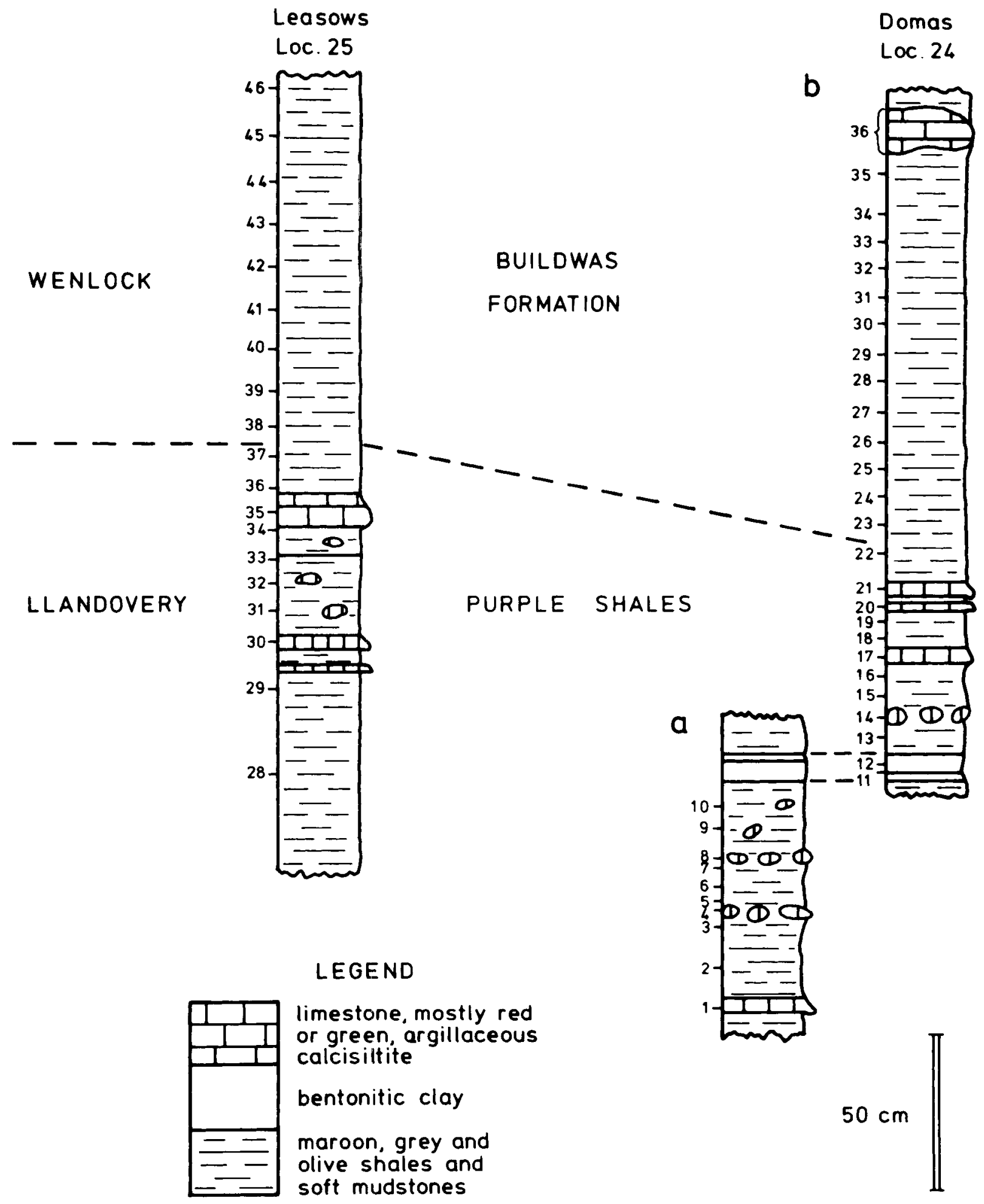

Fig. 2. Lithological sections. The Domas section comprises two separate exposures $2 \mathrm{~m}$. apart; the bentonitic clay serves as a datum plane to relate the sequences. 
different lengths and diameters are assigned to Hyperammina spp. Most specimens are poorly preserved and none has a recognisable proloculus (PI. 1, figs. 6-7). Rare specimens of $H$. harrisi Ireland, obtained from limestone residues, are more complete (Pl. 1, fig. 5). Branching forms are of two types: narrow, delicate, irregularly bifurcating specimens ( $\mathrm{Pl}$. 1, figs. 2-3), which resemble the illustrations by Mound (1968) of Rhabdammina irregularis Carpenter, and specimens of greater diameter with a single bifurcation (PI. 1, fig. 4), which are similar to Rhabdammina bifurcata Brown \&. Schott.

Of the species with inflated tests, common in the limestones of the Purple Shales, Webbinelloidea tholus is particularly frequent. The populations of this species comprise an assortment of morphologies which result from the linking of the hemispherical chambers to form doublets, triplets, chains, rings and clusters (Pl. 1, figs. 17-19, Pl. 2, figs. 1-5). Of similar shape, but occurring only as single chambers, is Hemisphaerammina sp. (Pl. 1, figs. 15, 16). Specimens of this species are distinguished from isolated chambers of $W$. tholus by their larger size, more coarsely granular test and the presence of a basal flange, when preserved. Large, nearly spherical specimens assigned to Psammosphaera cava are almost smooth and mostly inaperturate, although a minority of individuals possess a slit (Pl. 1, figs. 8-10).

Specimens referred to Lagenammina occurred only in residues from shale samples, particularly those from the Buildwas Formation. The genus is represented by shortnecked and long-necked forms (Pl. 1, figs. 11-12), the latter resembling the illustrations by McClellan (1966) of $L$. cumberlandiae (Conkin). Specimens tentatively referred to Astrorhiza? sp. (Pl. 1, fig. 1) and Thurammina? sp. (Pl. 1, fig. 14) are uncommon and poorly preserved. Small numbers of specimens assigned to Lituotuba? (Pl. 2, figs. 18-20) occur in shales and limestones of the Buildwas Formation. The species Turritellella workmani Dunn (Pl. 2, fig. 17) and Thurammina irregularis Moreman (Pl. 1, fig. 13) are represented by single specimens only.

It is not easy to assess the environmental significance of the changes recognised in arenaceous foraminiferal assemblages through our sections. In Recent seas, arenaceous foraminifera are most abundant in marginal environments (Phleger, 1960), but during the Silurian they probably filled most benthic niches occupied today by calcareous species. Palaeoecological analysis of Lower Palaeozoic forms has rarely been attempted, but recently Toomey (in Amsden et al., 1980) has interpreted the modes of life and habitats of several species of Wenlock age from Oklahoma. The assemblages he records are similar to ours in many respects and the same ecological groups appear to be present. Thus, benthic encrusters with hemispherical tests are represented by $W$. tholus and Hemisphaerammina, and vagile benthic browsers by $A$. exsertus, $P$. cava and Lagenammina. Tubular species, such as $H$. harrisi, probably lived interstitially within the sediment, but close to the surface.

All three ecological groups occur in the Purple Shales, with the epifaunal $A$. exsertus and $W$. tholus being particularly abundant. In the Buildwas Formation, interstitial forms are dominant, with Lagenammina representing the benthic browsers. Modern agglutinated browsers and encrusters are intimately associated with marine plants, and Toomey (in Amsden et al., 1980) has suggested

\section{Explanation of Plate 1}

All figures are $\mathrm{x} 60$. Specimens are deposited in the collections of the British Museum (Natural History), London. Fig. 1. Astrorhiza? sp.: upper view, P51129, sample 25/41.

Figs. 2, 3. Rhabdammina sp. cf. R. irregularis Carpenter: P51130 and P51131, sample 24/20.

Fig. 4. Rhabdammina sp. cf. $R$. bifurcata Brown \& Schott: P51132, sample 24/18.

Fig. 5. Hyperammina harrisi Ireland: P51133, sample 25/30.

Figs. 6, 7. Hyperammina spp.: P51134, sample 24/30 and P51135, sample 25/34.

Figs. 8-10. Psammosphaera cava Moreman: P51136, P51137 and P51138, all from sample 25/30.

Fig. 11. Lagenammina sp. cf. L. cumberlandiae (Conkin): lateral view P51139, sample 24/18.

Fig. 12. Lagenammina sp.: lateral view, P51140, sample 24/31.

Fig. 13. Thurammina irregularis Moreman: P51141, sample 24/4.

Fig. 14. Thurammina sp.: P51142, sample 24/30.

Fig. 15. Hemisphaerammina sp.: broken specimen overgrowing four-chambered specimen of W. tholus, P51143, sample $24,16$.

Fig. 16. Hemisphaerammina sp.: lateral view, P51144, sample 24/20.

Figs. 17, 18. Webbinelloidea tholus (Moreman): basal view, P51145, and lateral view, P51146, both from sample $25 / 30$.

Fig. 19. Webbinelloidea tholus (Moreman). Three-chambered specimen, P51147, overgrowing conodont element ( $\mathrm{Pb}$ of Pterospathodus amorphognathoides Walliser), sample 25/35. 

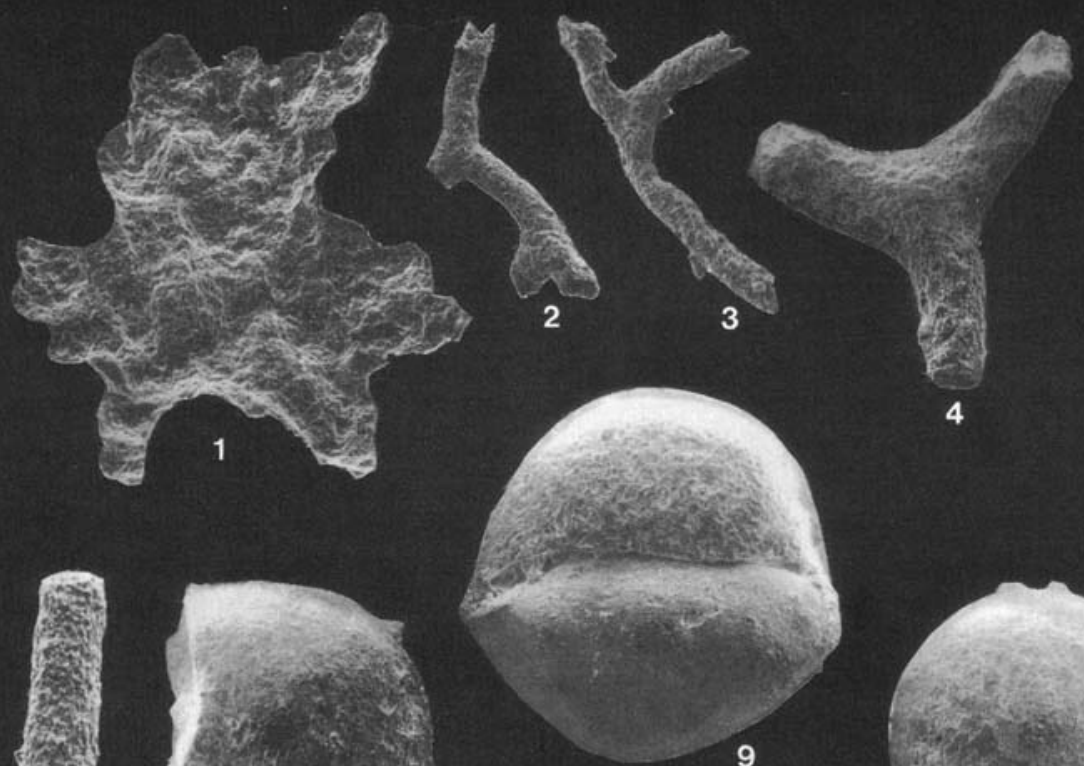

4

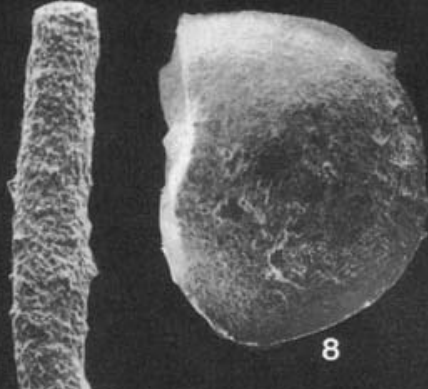

9
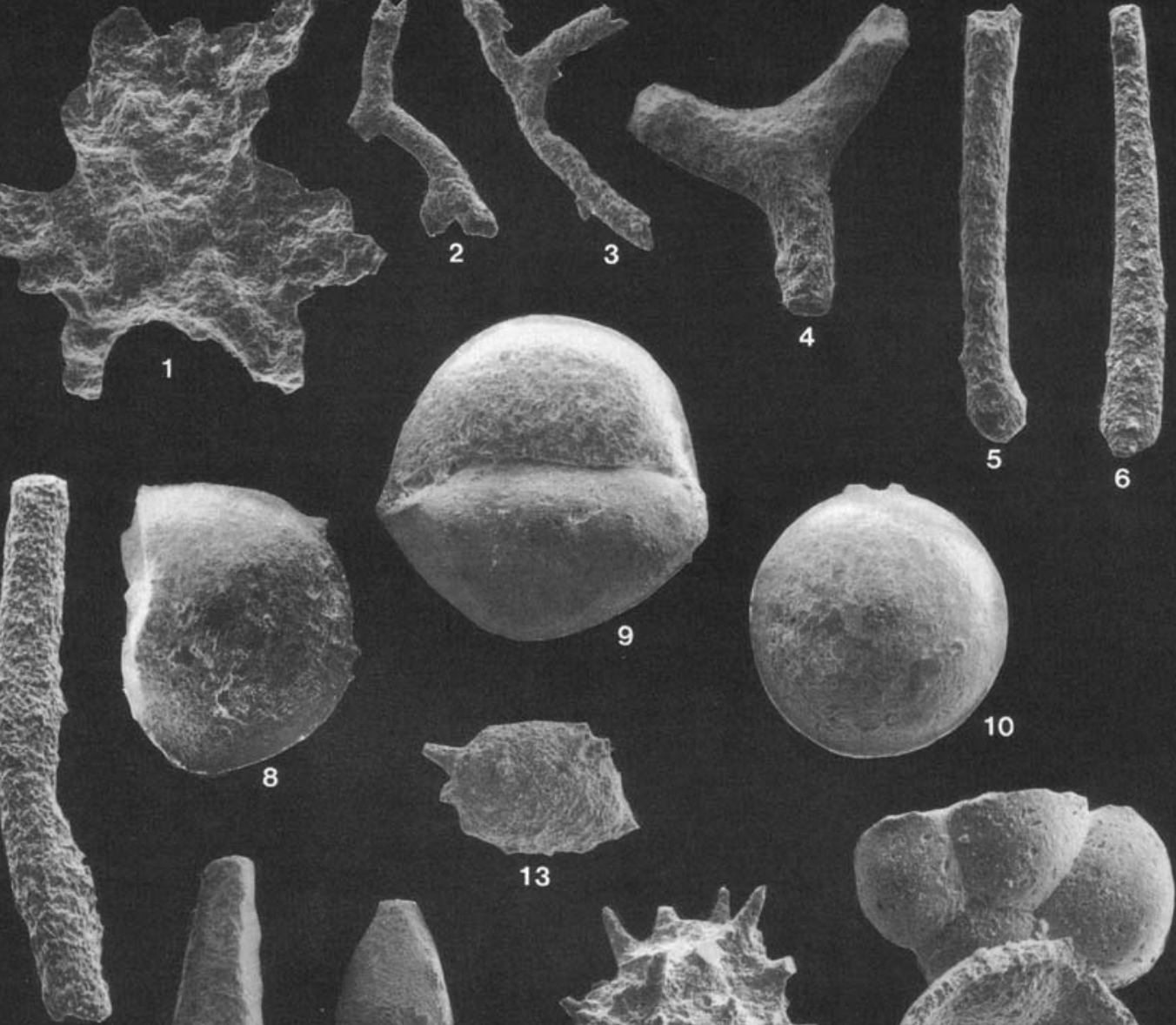

13
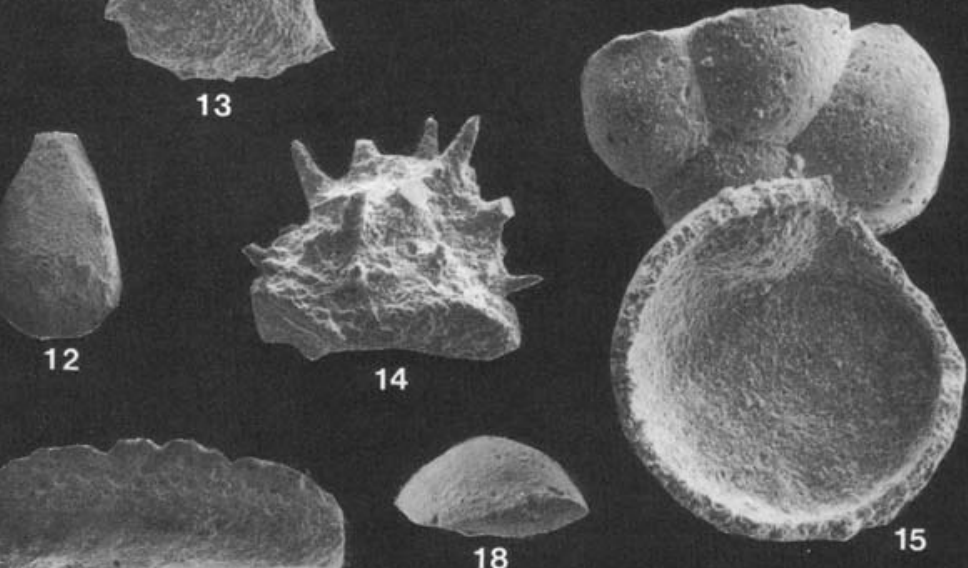

18

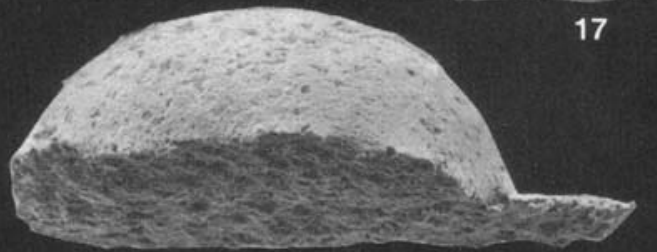

16 


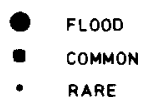

7 limestone and calcareous Siltstone

LEASOWS

LOCALITY 25
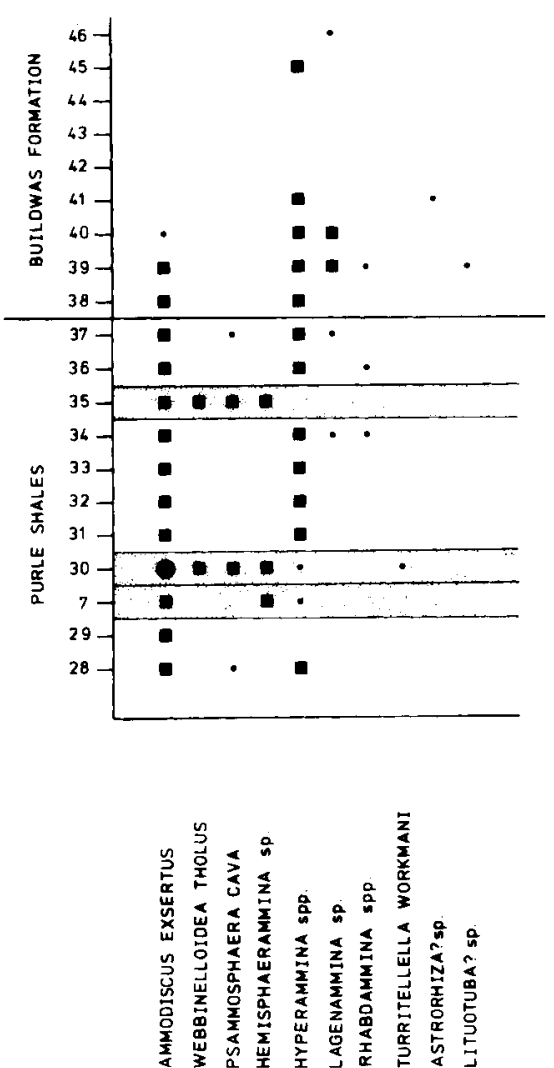

DOMAS

LOCALITY 24
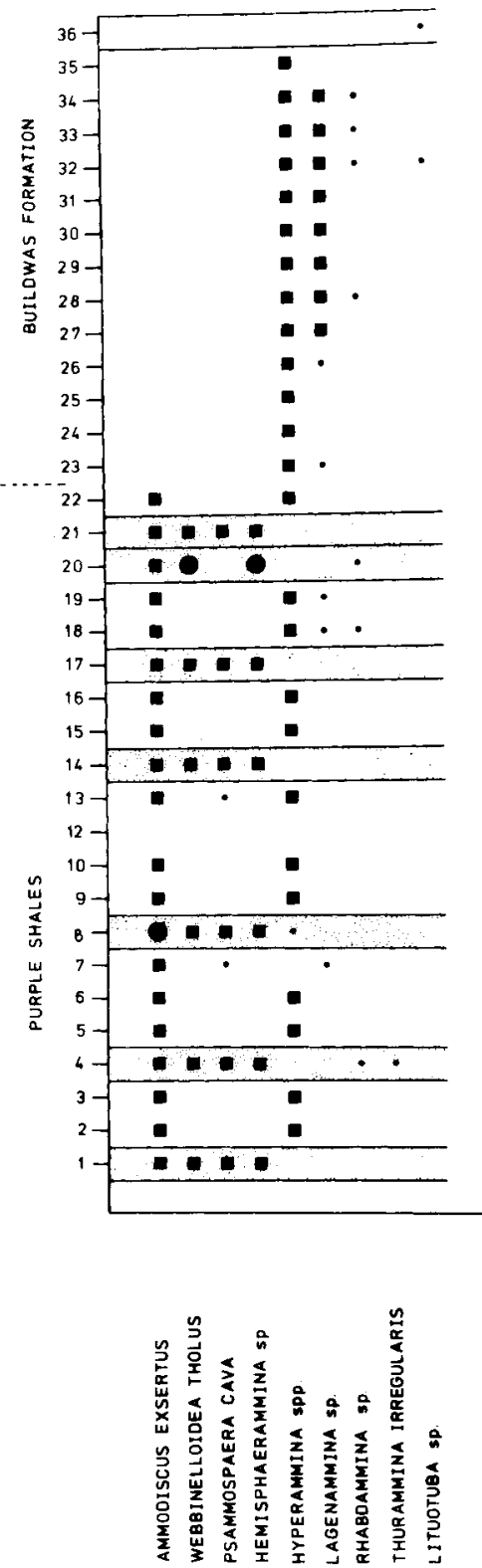

Fig. 3. Distribution and relative abundance of foraminifera through the two sections.

\section{Explanation of Plate 2}

All figures are $\mathrm{x} 60$. Specimens are deposited in the collections of the British Museum (Natural History), London.

Figs. 1-2. Webbinelloidea tholus (Moreman): upper view, P51148, sample 24/4 and basal view, P51149, sample 24/8. Fig. 3. Webbinelloidea tholus (Moreman): P51150, with false ornament on attachment surface, sample $25 / 32$.

Figs. 4-5. Webbinelloidea tholus (Moreman): lateral view, P51151, sample 24/8 and basal view, P51152, sample 24/17. Figs. 6-16. Ammodiscus exsertus Cushman: specimens P51153, P51154, P51155. P51156, P51157, P51158, P51159, P51160, P51161, P51162 and P51163, all from sample 25/30.

Fig. 17. Turritellella workmani Dunn: P51164, sample 25/30.

Figs. 18-20. Lituotuba? sp.: P51165, sample 24/30 and internal moulds, P51166 and P51167, both from sample 24/36. 


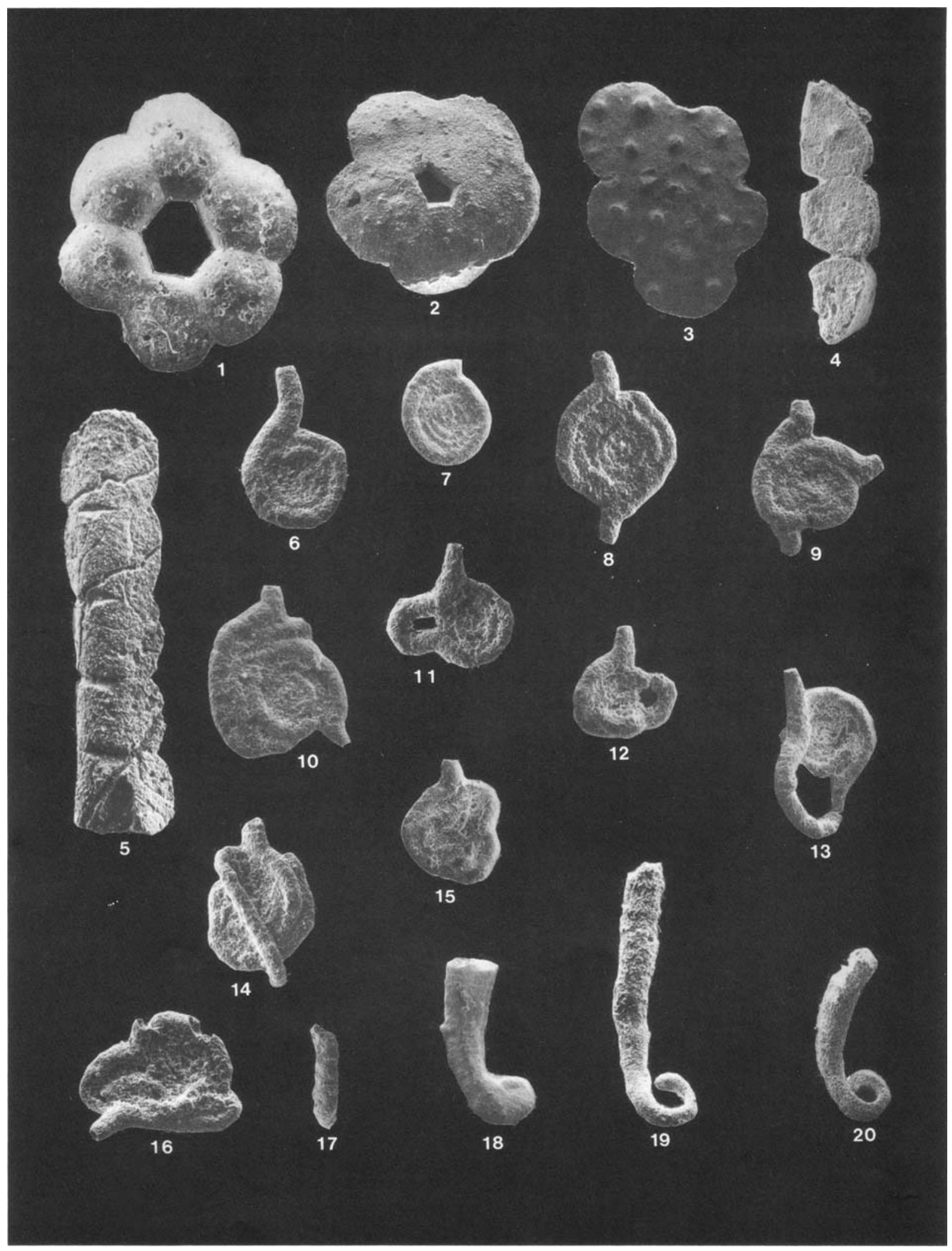


that algae with a grass-like habit may have formed a comparable habitat on the Silurian sea floor. If so, environmental changes influencing marine plants, themselves not preserved, would be manifested in changes in the associated foraminiferal faunas. Thus, the floods of epifaunal browsers in the Purple Shales and their relative demise in the Buildwas Formation may reflect expansions and contractions of plant habitats.

Too little is known about Silurian foraminifera for us to detect any species of potential biostratigraphical value. Murray (1981) has suggested that the likelihood of foraminifera being good index fossils for the Lower Palaeozoic is poor, and there is nothing in our study that allows contradiction of this view. Although several species, including $H$. harrisi, $T$. irregularis, $W$. tholus and $P$. cava are known only from the Silurian, their distribution patterns seem to reflect environmental, rather than evolutionary, controls.

\section{ACKNOW LEDGEMENTS}

J.E.M. acknowledges the award of a research studentship grant by the N.E.R.C. For cartographic assistance we thank Mrs. J. Wilkinson, and for help with photography we are grateful to Mr. L. Green and Mr. D. Jones.

\section{REFERENCES}

Aldridge, R.J., Dorning, K.J. Hill, P.J., Richardson, J.B. \& Siveter, D.J. 1979. Microfossil distribution in the Silurian of Britain and Ireland. In Harris, A.L., Holland, C.H.\& Leake, B.E. (Eds.), The Caledonides of the British Isles - reviewed, 433-438. Scottish Academic Press for The Geological Socicty of London.
Amsden, T.W., Toomey, D.F. \& Barrick, J.E. 1980. Palaeoenvironment of Fitzhugh Member of Clarita Formation (Silurian, Wenlockian) Southern Oklahoma. Oklahoma geol. Surv. Circular, Norman, 83, 54 pp., 21 figs., 3 tables, 7 pls.

Bassett, M.G., Cocks, L.R.M., Holland, C.H., Rickards, R.B.\& Warren, P.T. 1975. The type Wenlock Series. Rep. Inst. Geol. Sci., London, 75/13, vi + 19 pp.

Brady, H.B. 1888. Notes on some Silurian Lagenae. Geol. Mag., London, 5, 481-484, pl. XIII.

Cummings, R.H. 1952. Saccamminopsis from the Silurian. Proc. Geol. Ass., London, 63, 220-226.

Holland, C.H. 1980. Silurian series and stages: decisions concerning chronostratigraphy. Lethaia, Oslo, 13, 238.

Ireland, H.A. 1958. Microfauna of Wenlockian and Ludlovian Silurian beds in Western England (abstract). Bull. geol. Soc. Amer., New York, 69, 1592.

Ireland, H.A. 1967. Microfossils from the Silurian of England (abstract). Bull. Amer. Ass. petrol Geol., Chicago, 51, 471.

McClellan, W.A. 1966. Arenaceous Foraminifera from the Waldron Shale (Niagaran) of Southeast Indiana. Bull. Amer. Paleont., Ithaca, New York, 50, no. 230 , 447-518, pls. 36-42.

Mound, M.C. 1968. Arenaceous Foraminifera and zonation of the Silurian rocks of northern Indiana. Bull. Indiana geol. Surv., Bloomington, 38, 126 pp., 7 pls.

Murray, J.W. 1981. Pre-Carboniferous faunas. In Jenkins, D.G. \& Murray, J.W. (Eds.), Stratigraphical Atlas of Fossil Foraminifera, 13-14. Ellis Horwood Ltd., Chichester for The British Micropalaeontological Society.

Phleger, F.B. 1960. Ecology and distribution of Recent Foraminiferida. John Hopkins, Baltimore.

Smith, J. 1881. Notes on a collection of bivalved Entomostraca and other Microzoa from the Upper Silurian strata of the Shropshire district. Geol. Mag., London, 8, 70-75. 